\title{
Leaf Colour Chart Based N Management for Yield, Nutrient Uptake and Yield of Rice Genotypes
}

\author{
Tauseef A. Bhat, R. Kotru, Akhil Verma*, Monzoor A. Ganai, \\ Latie, Latief A. Dar and Nazeer A. Teli \\ Division of Agonomy Sher-e-Kashmir University of Agricultural Sciences and \\ Technology of Kashmir Shalimar, India \\ *Corresponding author
}

\section{A B S T R A C T}

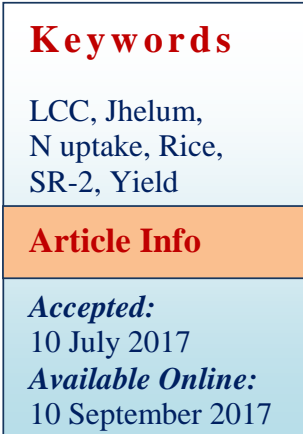

A field experiment was conducted at Research farm of Sher-e-Kashmir University of Agricultural Sciences and Technology of Kashmir, in silty clay loam soil to study the LCC based $\mathrm{N}$ management on yield, nutrient uptake and soil available status in two rice genotypes (Jhelum and SR-2) under irrigated conditions. The experiment was laid out in randomized block design with three replications. The treatments included 6 LCC based N management for two rice genotypes which consist of Jhelum and SR-2 were compared with the zero $\mathrm{N}$ control and a recommended fixed time $\mathrm{N}$ splitting. The results suggested that yield and NPK uptake were significantly higher in LCC $\leq 5 @ 30$ and $20 \mathrm{~kg} \mathrm{~N} \mathrm{ha}^{-1}$ as compared to other LCC levels (LCC $\leq 4$ and $3 @ 30$ and $20 \mathrm{~kg} \mathrm{~N} \mathrm{ha}^{-1}$ ) and recommended nitrogen level. Among the two cultivars, SR-2 recorded significantly higher yield and NPK uptake over Jhelum. The results further revealed that plots with Jhelum recorded significantly more soil available NPK as compared to SR-2. The lack of difference in soil available nutrient between LCC based treatments and conventional blanket $\mathrm{N}$ treatment suggest that LCC based $\mathrm{N}$ management could be best option for farmers to save fertilizer $\mathrm{N}$ besides maintaining soil fertility.

\section{Introduction}

Rice is the most vital food crop and a major food grain for more than a third of the world's population. Nitrogen $(\mathrm{N})$ is the most widely used fertilizer nutrient in rice and its consumption has increased substantially in the past decades. The quantity of rice grain produced per unit of applied $\mathrm{N}$ fertilizer (partial factor productivity) has continuously decreased to very low values (Dobermann et $a l ., 2002)$. Application of nitrogen fertilizer in fixed time recommended $\mathrm{N}$ split schedule, without taking into account whether the plant really requires $\mathrm{N}$ at the time which may lead to loss or may not be found adequate enough to synchronize nitrogen supply with actual crop nitrogen demand (Ladha et al., 2000). Unbalanced and excessive use of $\mathrm{N}$-fertilizers causes environmental pollution, lodging of plants and increased pest pressure, in addition to increased cost to farmers from excessively applied fertilizers and pesticides. Approaches such as deep placement of urea super granules, controlled release $\mathrm{N}$ fertilizers and nitrification inhibitors based on reducing $\mathrm{N}$ 
losses have been successful in improving fertilizer $\mathrm{N}$ use efficiency but to a limited extent. Since farmers generally prefer to keep leaves of the crop dark green, it leads to over application of fertilizer $\mathrm{N}$ resulting in low use efficiency. Thus, the spectral properties of leaves should be used in a more rational manner to guide need based $\mathrm{N}$ applications. $\mathrm{N}$ application at the right time and in right dose is critical for healthy plant environment. Rice leaf color intensity is directly related to leaf chlorophyll content and leaf nitrogen status. The concept for the use of leaf color as an indicator to apply $\mathrm{N}$ in rice was evaluated during 1990s. The International Rice Research Institute and the Philippine Rice Research Institute developed a leaf color chart (LCC) that helps to guide farmers for realtime nitrogen management in rice farming. The technology is inexpensive, and easily affordable by most resource poor rice farmers (Islam et al., 2004).

\section{Materials and Methods}

A field experiment was conducted during kharif season of 2012 and 2013 with rice genotypes at Sher-e-Kashmir University of Agricultural sciences and Technology of Kashmir Research Farm at Shalimar (34-08' $\mathrm{N}$ latitude and 74-83' East longitude and 1587 $\mathrm{m}$ above the mean sea level). The soil of the experimental field was silty clay loam containing $0.92 \%$ organic $\mathrm{C}$, with $p \mathrm{H}$ 6.6, EC $0.22 \mathrm{dS} \mathrm{m}^{-1}$, available $\mathrm{N} 308.96 \mathrm{~kg} \mathrm{ha}^{-1}, \mathrm{P}$ $33.38 \mathrm{~kg} \mathrm{ha}$ and ammonium acetate extractable K $169.26 \mathrm{~kg} \mathrm{ha}^{-1}$ (Table 1). The meteorological data were recorded daily from sowing until harvest by meteorological observatory located near the experimental field. Under average climatic conditions, the area receives $690 \mathrm{~mm}$ of mean annual rainfall most of which occurs from December to April. Rainfall received during the ricegrowing season (June to September) was 222.2 and $375 \mathrm{~mm}$ during 2012 and 2013, respectively. The mean monthly maximum and minimum temperatures during the rice growing seasons varied from 9.94 to $19.36{ }^{\circ} \mathrm{C}$ and 9.51to $19.11{ }^{\circ} \mathrm{C}$ and 22.14 to $32.36{ }^{\circ} \mathrm{C}$ and 22.96 to $32.50{ }^{\circ} \mathrm{C}$, during 2012 and 2013, respectively.

\section{Experimental design and treatments}

The experiment was laid out in randomized block design with three replications. The treatments included two rice genotypes and eight rates of $\mathrm{N}$ application (control, recommended practice and $\mathrm{LCC} \leq 3,4$ and 5 @ 20 and $30 \mathrm{~kg} \mathrm{~N} / \mathrm{ha}$ ). In the recommended $\mathrm{N}$ rate treatment, $\mathrm{N}$ was applied in three equal splits $\left(1 / 2,1 / 4\right.$ and $1 / 4$ total $\left.\mathrm{kg} \mathrm{N} \mathrm{ha}^{-1}\right)$ at transplanting (basal), mid-tillering and panicle initiation. Nitrogen was applied in form of urea as per treatment schedule.

\section{Crop management}

Field preparation for rice included two disc ploughings in dry soil followed by two puddlings. Thirty five days old seedlings of rice genotypes were transplanted manually at $15 \times 15 \mathrm{~cm}$ in the second week of June. All the treatment plots received uniform dose of $60 \mathrm{~kg} \mathrm{P} \mathrm{ha}{ }^{-1}, 30 \mathrm{~kg} \mathrm{~K} \mathrm{ha}^{-1}$ and $15 \mathrm{~kg}$ zinc sulphate $\mathrm{ha}^{-1}$. Whole of the $\mathrm{P}, \mathrm{K}$ and $\mathrm{Zn}$ were applied into the soil as basal dose before transplanting. The crop was irrigated daily during the first two weeks and thereafter as needed to prevent the soil surface from being without Hand weeding was done and standard cultural practices were carried out until the crop was mature. Rice was harvested manually in the third week of September.

\section{Leaf colour chart measurement}

The LCC jointly developed by International Rice Research Institute (IRRI) and Philippine Rice Research Institute (PhilRice), consisting of six green shades from yellowish green to dark green, showing increasing greenness with increasing number, was used in this 
study. LCC readings were taken at 4 days interval starting from 12 DAT till $50 \%$ flowering. 10 disease free rice plants were randomly selected in the plot, and the color of the youngest fully expanded leaf of the selected plant was compared by placing its middle part on top of the color strip in the chart. If $2 / 3$ or more leaves read equal or below the treatments critical value (of LCC 3, 4 or 5), a dose of 30 and $20 \mathrm{~kg} \mathrm{~N} \mathrm{ha}^{-1}$ was applied as per treatment schedule (Table 2).

\section{Plant sampling and analysis}

Plant samples were collected from half meter row length from each plot at 20 days interval from 20 DAT till harvesting the crop for calculating dry matter accumulation. After sun drying from 4-6 days, the samples were dried in an oven for about 24 hours at temperature of $65^{\circ} \mathrm{C}$ till constant weight was achieved. Dry weight of plant samples was recorded in grams per half meter row length and then converted in to $\mathrm{q} \mathrm{ha}{ }^{-1}$. Grain and straw yields were determined from an area of $12.36 \mathrm{~m}^{2}$ located in the center of each treatment plot at harvestable maturity. Grain yields are reported at $14 \%$ water content fresh weight. Grain weight was determined after separated from straw. The grain plus separated straw were dried in an oven at $70^{\circ} \mathrm{C}$ for 48 hours to achieve constant weight. Nitrogen content in grain and straw was determined by digesting the samples in sulfuric acid $\left(\mathrm{H}_{2} \mathrm{SO}_{4}\right)$, followed by analysis of total $\mathrm{N}$ by the Kjeldahl method using a Kjeltec autoanalyzer. $\mathrm{P}$ content in grain and straw was estimated by Vanado-molybdo phosphoric yellow using systronics spectrometer after digestion in diacid $\left(\mathrm{HNO}_{3}: \mathrm{HClO}_{4}\right.$ in ratio of $\left.9: 4\right)$ whereas $\mathrm{K}$ content from grain and straw was estimated after digestion from tri-acid using Flame photometer. Soil available N (Subbiah and Asija, 1956), $\mathrm{P}\left(0.5 \mathrm{~N} \mathrm{NaHCO}_{3}\right.$ by Olsen et $a l ., 1954)$ and $\mathrm{K}(1 \mathrm{~N}$ ammonium acetate method by Jackson, 1973) were estimated after the harvest of crop.

\section{Data analysis}

Analysis of variance (ANOVA) was performed using SPSS software. Least significance difference (LSD) at a 0.05 level of probability was used to test the significance of differences among treatment means (Cochran and Cox, 1955).

\section{Results and Discussion}

\section{LCC and N saving}

Use of LCC with a critical shade $4 @ 20 \mathrm{~N}$ $\mathrm{ha}^{-1}$ in rice genotypes resulted in the application of $100 \mathrm{~kg} \mathrm{~N}^{-1}$, thus effecting a saving of $20 \mathrm{~kg} \mathrm{~N} \mathrm{ha}^{-1}$ with higher values of yield compared to application $120 \mathrm{~kg} \mathrm{~N} \mathrm{ha}^{-1}$ in three equal splits at fixed growth stages, depending on the variability of soil and climate (Table 2). Management of $\mathrm{N}$ using LCC shade as threshold greenness of leaves 5 @ 20 and $30 \mathrm{~kg} \mathrm{~N} \mathrm{ha}{ }^{-1}$ resulted in the application of high rates of $\mathrm{N}(120$ and $150 \mathrm{~kg}$ $\mathrm{N} \mathrm{ha}^{-1}$ ) during the both the years of the study. Likewise, LCC shade as threshold value of 3 @ 20 and $30 \mathrm{~kg} \mathrm{~N} / \mathrm{ha}$ resulted in the application of 80 and $90 \mathrm{~kg} \mathrm{~N} \mathrm{ha}{ }^{-1}$, thus saving 40 and $30 \mathrm{~kg} \mathrm{~N} \mathrm{ha-1}$ compared to recommended nitrogen application without any reduction in yield. LCC threshold value 5 @ 20 and $30 \mathrm{~kg} \mathrm{~N} \mathrm{ha}^{-1}$ seems to be optimum for need-based $\mathrm{N}$ application to rice genotypes.

\section{Grain yield}

Significant effect of real time nitrogen management through LCC and rice genotypes was found on the grain yield (Table 3). The data revealed that SR-2 recorded significantly higher grain yield than cultivar Jhelum during both the years. 
Table.1 Physico-chemical properties of soil of experimental field before the start of experiment

\begin{tabular}{|c|c|c|c|}
\hline Particulars & Status & Rating & Method Applied \\
\hline \multicolumn{4}{|l|}{ A. Particle size distribution } \\
\hline Coarse sand \% & 1.5 & - & \multirow{5}{*}{$\begin{array}{l}\text { International Pipette } \\
\text { Method (Piper, 1966) }\end{array}$} \\
\hline Fine sand \% & 17.7 & - & \\
\hline Silt \% & 41.8 & - & \\
\hline Clay \% & 39.0 & - & \\
\hline Texture & $\begin{array}{l}\text { Silty } \\
\text { clay } \\
\text { loam }\end{array}$ & - & \\
\hline \multicolumn{4}{|l|}{ B. Chemical characteristics } \\
\hline $\mathrm{pH}(1: 2.5$ soil water suspension $)$ & 6.6 & Normal & $\begin{array}{l}\text { Blackman's glass electrode } \\
\text { pH meter (Jackson, 1973) }\end{array}$ \\
\hline $\begin{array}{l}\text { Electrical conductivity } \mathrm{dSm}^{-1} \text { at } \\
25^{\circ} \mathrm{C}\end{array}$ & 0.22 & Normal & $\begin{array}{l}\text { Sloubridge conductivity } \\
\text { meter (Piper, 1966) }\end{array}$ \\
\hline Organic carbon $\%$ & 0.92 & High & $\begin{array}{l}\text { Walkely and Black (1934) } \\
\text { rapid titration method }\end{array}$ \\
\hline Available nitrogen $\left(\mathrm{kg} \mathrm{ha}^{-1}\right)$ & 308.96 & Medium & $\begin{array}{l}\text { Alkaline } \\
\text { permanganate } \\
\text { (Subbiah and Asija, 1956) }\end{array}$ \\
\hline Available phosphorus $\left(\mathrm{kg} \mathrm{ha}^{-1}\right)$ & 33.38 & High & Olsen et al., 1954 \\
\hline Available potassium $\left(\mathrm{kg} \mathrm{ha}^{-1}\right)$ & 169.26 & Medium & $\begin{array}{l}\text { Ammonium acetate } \\
\text { method (Jackson, 1973) }\end{array}$ \\
\hline
\end{tabular}

Table.2 Total quantity of nitrogen applied under different treatments in rice cultivars viz Jhelum and SR-2 during 2012 and 2013

\begin{tabular}{|c|c|c|}
\hline Treatments & Number of splits & Total N applied \\
\hline Absolute control & $\mathbf{0}$ & $\mathbf{0}$ \\
\hline Recommended dosage of N & $\mathbf{3}$ & $\mathbf{1 2 0}$ \\
\hline LCC $\leq 3$ at $20 \mathrm{~kg} \mathrm{~N} \mathrm{ha}^{-1}$ & $\mathbf{4}$ & $\mathbf{8 0}$ \\
\hline LCC $\leq 3$ at $30 \mathrm{~kg} \mathrm{Nha}^{-1}$ & $\mathbf{3}$ & $\mathbf{9 0}$ \\
\hline LCC $\leq 4$ at $20 \mathrm{~kg} \mathrm{Nha}^{-1}$ & $\mathbf{5}$ & $\mathbf{1 0 0}$ \\
\hline LCC $\leq 4$ at $30 \mathrm{~kg} \mathrm{Nha}^{-1}$ & $\mathbf{4}$ & $\mathbf{1 2 0}$ \\
\hline LCC $\leq 5$ at $20 \mathrm{~kg} \mathrm{~N} \mathrm{ha}^{-1}$ & $\mathbf{6}$ & $\mathbf{1 2 0}$ \\
\hline LCC $\leq 5$ at $30 \mathrm{~kg} \mathrm{~N} \mathrm{ha}^{-1}$ & $\mathbf{5}$ & $\mathbf{1 5 0}$ \\
\hline
\end{tabular}


Table.3 Effect of real time nitrogen management through LCC and rice genotypes on grain yield and NPK uptake

\begin{tabular}{|c|c|c|c|c|c|c|c|c|c|c|c|c|c|c|}
\hline \multirow[t]{3}{*}{ Treatments } & \multirow{2}{*}{\multicolumn{2}{|c|}{$\begin{array}{l}\text { Grain yield } \\
\qquad\left(\mathbf{q ~ h a} \mathbf{p}^{-1}\right)\end{array}$}} & \multicolumn{4}{|c|}{$\begin{array}{c}\text { N uptake } \\
\left(\mathrm{kg} \mathrm{ha}^{-1}\right)\end{array}$} & \multicolumn{4}{|c|}{$\begin{array}{l}\text { P uptake } \\
\left(\mathrm{kg} \mathrm{ha}^{-1}\right)\end{array}$} & \multicolumn{4}{|c|}{$\begin{array}{l}\text { K uptake } \\
\left(\mathrm{kg} \mathrm{ha}^{-1}\right)\end{array}$} \\
\hline & & & \multicolumn{2}{|c|}{ Grain } & \multicolumn{2}{|c|}{ Straw } & \multicolumn{2}{|c|}{ Grain } & \multicolumn{2}{|c|}{ Straw } & \multicolumn{2}{|c|}{ Grain } & \multicolumn{2}{|c|}{ Straw } \\
\hline & 2012 & 2013 & 2012 & 2013 & 2012 & 2013 & 2012 & 2013 & 2012 & 2013 & 2012 & 2013 & 2012 & 2013 \\
\hline \multicolumn{15}{|c|}{ Varieties } \\
\hline Jhelum & 63.95 & 67.67 & 75.46 & 81.88 & 35.29 & 42.00 & 13.43 & 14.89 & 4.81 & 5.88 & 19.82 & 21.65 & 121.90 & 129.34 \\
\hline SR-2 & 72.18 & 74.31 & 86.62 & 91.40 & 39.37 & 45.92 & 15.88 & 17.09 & 5.99 & 7.06 & 23.10 & 24.52 & 131.81 & 137.75 \\
\hline \pm SEm & 0.84 & 0.75 & 1.49 & 1.52 & 0.70 & 0.71 & 0.58 & 0.65 & 0.35 & 0.36 & 0.90 & 0.64 & 1.86 & 1.81 \\
\hline C.D $(p \leq 0.05)$ & 2.54 & 2.25 & 4.49 & 4.67 & 2.20 & 2.15 & 1.74 & 1.95 & 1.06 & 1.08 & 2.72 & 1.85 & 3.26 & 4.43 \\
\hline \multicolumn{15}{|c|}{ Nitrogen management } \\
\hline Control & 39.16 & 42.13 & 46.21 & 50.56 & 26.56 & 29.07 & 7.83 & 8.85 & 3.46 & 4.24 & 11.36 & 12.64 & 87.75 & 92.67 \\
\hline Recommended N & 70.07 & 72.87 & 84.08 & 88.90 & 40.42 & 43.61 & 15.42 & 16.76 & 6.74 & 7.85 & 21.72 & 23.32 & 130.53 & 136.05 \\
\hline$\frac{\mathrm{LCC} \leq 3 @ 20}{\mathrm{ha}^{-1}} \mathrm{~N} \mathrm{~kg}$ & 66.10 & 69.24 & 78.66 & 83.78 & 37.56 & 40.70 & 13.88 & 15.23 & 5.59 & 6.64 & 19.83 & 21.46 & 122.28 & 127.91 \\
\hline$\frac{\mathrm{LCC} \leq 3 @, 30}{\mathrm{ha}^{-1}} \mathrm{~N} \mathrm{~kg}$ & 68.57 & 71.54 & 82.28 & 87.28 & 39.56 & 42.88 & 15.09 & 16.45 & 5.77 & 6.86 & 21.26 & 22.89 & 126.93 & 132.91 \\
\hline$\frac{\mathrm{LCC} \leq 4 @ 20}{\mathrm{ha}^{-1}} \mathrm{~N} \mathrm{~kg}$ & 72.84 & 75.63 & 88.14 & 93.02 & 42.78 & 45.80 & 16.75 & 18.15 & 6.98 & 8.08 & 23.31 & 24.96 & 136.20 & 141.00 \\
\hline$\frac{\mathrm{LCC} \leq 4 @, 30}{\mathrm{ha}^{-1}} \mathrm{~N} \mathrm{~kg}$ & 73.77 & 76.92 & 90.00 & 95.38 & 43.45 & 47.01 & 17.70 & 19.23 & 7.09 & 8.30 & 24.34 & 26.15 & 138.33 & 144.71 \\
\hline$\frac{\mathrm{LCC} \leq 5 @ 20}{\mathrm{ha}^{-1}} \mathrm{~N} \mathrm{~kg}$ & 77.80 & 79.77 & 95.69 & 99.71 & 45.42 & 49.28 & 18.67 & 19.94 & 8.17 & 8.53 & 25.67 & 27.12 & 142.60 & 149.74 \\
\hline$\frac{\mathrm{LCC} \leq 5 @ 30}{\mathrm{ha}^{-1}} \mathrm{Nkg}$ & 80.21 & 82.84 & 99.46 & 104.38 & 47.99 & 51.77 & 20.05 & 21.54 & 8.47 & 9.27 & 26.47 & 28.17 & 147.74 & 155.30 \\
\hline \pm SEm & 1.70 & 1.74 & 2.81 & 3.04 & 1.04 & 1.20 & 1.14 & 1.63 & 0.46 & 0.39 & 0.47 & 0.61 & 1.75 & 3.14 \\
\hline C.D $(p \leq 0.05)$ & 5.10 & 5.22 & 8.40 & 9.12 & 3.11 & 3.60 & 3.44 & 3.18 & 1.39 & 1.18 & 1.42 & 1.80 & 5.26 & 9.42 \\
\hline
\end{tabular}


Table.4 Effect of real time N management through LCC and rice genotypes on soil available NPK

\begin{tabular}{|c|c|c|c|c|c|c|}
\hline \multirow[t]{2}{*}{ Treatments } & \multicolumn{2}{|c|}{$\begin{array}{l}\text { Available } \\
\text { Nitrogen } \\
\left(\text { kg ha }^{-1}\right)\end{array}$} & \multicolumn{2}{|c|}{$\begin{array}{c}\text { Available } \\
\text { Phosphorus } \\
\left(\text { kg ha }^{-1}\right)\end{array}$} & \multicolumn{2}{|c|}{$\begin{array}{c}\text { Available } \\
\text { Potassium } \\
\left(\mathrm{kg} \mathrm{ha}^{-1}\right)\end{array}$} \\
\hline & 2012 & 2013 & 2012 & 2013 & 2012 & 2013 \\
\hline \multicolumn{7}{|c|}{ Varieties } \\
\hline Jhelum & 286.37 & 288.10 & 29.01 & 30.01 & 166.15 & 167.20 \\
\hline SR-2 & 272.24 & 275.60 & 27.48 & 29.29 & 165.16 & 166.19 \\
\hline \pm SEm & 1.60 & 1.31 & 0.62 & 0.43 & 0.47 & 0.38 \\
\hline C.D $(p \leq 0.05)$ & 4.80 & 3.94 & 1.86 & 1.30 & $\mathrm{NS}$ & $\mathrm{NS}$ \\
\hline \multicolumn{7}{|c|}{ Nitrogen management } \\
\hline Control & 243.49 & 245.89 & 21.93 & 22.93 & 158.86 & 159.86 \\
\hline Recommended N & 284.64 & 286.39 & 25.48 & 26.48 & 164.75 & 165.75 \\
\hline $\mathrm{LCC} \leq 3 @ 20 \mathrm{~N} \mathrm{~kg} \mathrm{ha}^{-1}$ & 268.66 & 270.23 & 35.23 & 36.20 & 172.97 & 173.97 \\
\hline $\mathrm{LCC}^{2} 3 @ 30 \mathrm{~N} \mathrm{~kg} \mathrm{ha}^{-1}$ & 274.16 & 276.87 & 33.10 & 34.14 & 171.41 & 172.41 \\
\hline $\mathrm{LCC} \leq 4 @ 20 \mathrm{~N} \mathrm{~kg} \mathrm{ha}^{-1}$ & 282.49 & 284.89 & 32.04 & 33.04 & 168.70 & 169.68 \\
\hline $\mathrm{LCC}^{2} 4 @ 30 \mathrm{~N} \mathrm{~kg} \mathrm{ha}^{-1}$ & 286.99 & 289.25 & 28.78 & 29.78 & 168.32 & 169.34 \\
\hline $\mathrm{LCC} \leq 5 @ 20 \mathrm{~N} \mathrm{~kg} \mathrm{ha}^{-1}$ & 294.33 & 296.23 & 25.19 & 26.19 & 160.51 & 162.51 \\
\hline LCC $\leq 5 @ 30 \mathrm{Nkgha}$ & 304.34 & 306.06 & 24.20 & 25.20 & 159.03 & 160.03 \\
\hline \pm SEm & 3.16 & 2.90 & 0.69 & 0.66 & 1.15 & 1.07 \\
\hline C.D $(p \leq 0.05)$ & 9.50 & 7.80 & 2.07 & 1.98 & 3.33 & 3.20 \\
\hline
\end{tabular}

The grain yield recorded with SR-2 was 72.18 and $74.31 \mathrm{q} \mathrm{ha}^{-1}$ in comparison to Jhelum with yield of 63.95 and $67.67 \mathrm{q} \mathrm{ha}^{-1}$ during 2012 and 2013, respectively. Since rice yield is dependent on the number of panicles $\mathrm{m}^{-2}$ and grains panicle ${ }^{-1}$ which were significantly higher in SR-2 and resulting in higher grain yield. SR-2 also produced significantly higher dry matter than Jhelum contributing to higher yield. Avijit et al., 2011 have also reported variation in the grain yield of different rice cultivars. LCC $\leq 5 @ 30$ and $20 \mathrm{~kg} \mathrm{~N} \mathrm{ha}^{-1}$ recorded significantly higher grain yield (80.21 and $82.84 \mathrm{q} \mathrm{ha}^{-1}$ and 77.80 and $79.7 \mathrm{q}$ $\mathrm{ha}^{-1}$ ) than LCC $\leq 4 @ 30$ and $20 \mathrm{~kg} \mathrm{~N} \mathrm{ha}^{-1}$ (73.77 and $76.92 \mathrm{q} \mathrm{ha}^{-1}$ and 72.84 and $75.63 \mathrm{q}$ $\left.\mathrm{ha}^{-1}\right), \mathrm{LCC} \leq 3 @ 30$ and $20 \mathrm{~kg} \mathrm{~N} \mathrm{ha}^{-1}(68.57$ and $71.54 \mathrm{q} \mathrm{ha}^{-1}$ and 66.10 and $69.24 \mathrm{q} \mathrm{ha}^{-1}$ ) and recommended application of nitrogen (70.07 and $72.87 \mathrm{q} \mathrm{ha}^{-1}$ ) during 2012 and 2013.
Higher grain yield obtained in LCC $\leq 5 @ 30$ and $20 \mathrm{~kg} \mathrm{~N} \mathrm{ha}{ }^{-1}$ might be due to higher quantity of nitrogen applied in more number of splits compared to other levels. These results are also in close conformity with the findings of Maiti and Das, (2006) who reported higher grain yield with LCC based nitrogen management. Application of nitrogen at LCC 5 matched the crop demand at different physiological stages and reduced the losses through denitrification, volatilization by applying nitrogen in more number of splits that resulted in highest grain yield (Porpavai et al., 2002).

\section{Acknowledgement}

Authors are highly grateful to INSPIRE-DST, New Delhi for funding this research programme to be carried out at Sher-eKashmir University of Agricultural sciences and Technology of Kashmir. 


\section{References}

Avijit, S., Srivastava, V.K., Singh, M.K., Singh, R.K. and Suneel, K. 2011. Leaf colour chart vis-a-vis nitrogen management in different rice genotypes. American Journal of Plant Sciences. 2(2): 223-236.

Bremner, J.M. and Mulvaney, C.S. 1983. Nitrogen-total, pp. 595-624. In Page et al., (eds) Methods of soil analysis. 2nd ed. ASA, Madison, WI, USA, 1983: p. 1159.

Cohran, W.G. and Cox, G.M. 1955. Experimental Design. John Willey \& Sons, New York.

Dobermann, A., Witt, C., Dawe, D., Gines, H.C., Nagarajan, R., Stawathananont, S., So, T.T., Tan, P.S., Wang, G.H., Chien, N.V., Thoa, V.T.K., Phung, C.V., Stalin, P., Muthukrishnan, P., Ravi, V., Babu, M., Chatuporn, S., Kongchum, M., Sun, Q., Fu, R., Simbahan, G. and Adviento, M.A.A. 2002. Site-specific nutrient management for intensive rice cropping systems in Asia. Field Crops Research. 74: 37-66.

Gupta, R.K., Varinderpal, S., Yadvinder, S., Bijay, S., Thind, H.S., Ajay, K. and Monika, V. 2011. Need-based fertilizer nitrogen management using leaf colour chart in hybrid rice (Oryza sativa). Indian Journal of Agricultural Sciences. 81(12): 1153-1157.

Islam, M.S., Bhuiya, M.S.U. and Rahman, S. 2004. Evaluation of SPAD and LCC based nitrogen management in rice (Oryza Sativa L.). Bangladesh Journal of Agrilcultural Research. 34(4): 661672 .

Jackson, M.L. 1973. Soil chemical Analysis Prentice hall of India Private Limited, New Delhi. 498.

Johnkutty, L., Kandawamy, O.S., Palaniappan, S.P. 2000. Time course Leaf $\mathrm{N}$ concentration in rice under different nitrogen application strategies and development of simulation models. Journal of Tropical Agriculture. 37:4045.

Ladha, J.K., Fischer, K.S., Hossain, M., Hobbs, P.R. and Hardy, B. 2000. "Improving the Productivity and Sustainability of Rice-Wheat Systems of the Indo-Gangetic Plains," A Synthesis of NARS-IRRI Partnership Research Discussion Paper 40, IRRI, Los Banos.

Mahajan, G., Sekhon, N.K., Singh, N., Kaur, R. and Sidhu, A.S. 2010. Yield and nitrogen-use efficiency of aromatic rice cultivars in response to nitrogen fertilizer. Journal of New Seeds. 11:356-368.

Maiti, D. and Das, D.K. 2006. Management of nitrogen through the use of leaf colour chart (LCC) and soil plant analysis development (SPAD) in wheat under irrigated ecosystem. Archives of Agronomy and Soil Science. 52(1): 105-112.

Nachimuthu, G., Velu, V., Malarvizhi, P., Ramasamy, S. and Gurusamy, L. 2007. Standardisation of Leaf Colour Chart based nitrogen management in direct wet seeded rice (Oryza sativa L.). Journal of Agronomy. 6(2): 338-343.

Olsen, S.R., Cole, C.V., Watanabe, F.S. and Dean, L.A. 1954. Estimation of available phosphorus by extraction with sodium bicarbonate. US Deparment of Agriculture, Circular 939.

Piper, C.S. 1966. Soil and Plant Analysis. Hans Publishers, Bombay.

Porpavai, S., Murali krishnasamy, Nadanassababady, Jayapaul, T.P. and Balasubramanian, V.2002. Standardising Critical Leaf Colour Chart values for transplanted rice in Cauvery New Delta. Agriculture Science Digest. 22(3): $207-208$.

Sikandar, M.S.I., Rahman, M.M., Islam, M.S., Yeasmin, M.S. and Akhter, M.M. 
2008. Effect of Nitrogen Level on Aromatic Rice Varieties and Soil Fertility Status. International Journal of Sustainable Crop Production. 3(3):4954.

Subbiah, B.V. and Asija, G.L. 1956. A rapid procedure for the estimation of available nitrogen in soils. Current Science. 25: 259-260.

Walkley, A. and Black, T.A. 1934. An examination of the digestion method for determining soil organic matter and a proposed modification of chromic acid titration method. Soil Science. 1: 37: 29-38.

Zaman, M.H. 1999. Improving nitrogen management for transplanted rice: Use of chlorophyll meter (SPAD 502), leaf colour chart (LCC) and controlled release nitrogen fertilizer, M.Sc. Thesis, Tamil Nadu Agricultural University, Coimbatore, India.

\section{How to cite this article:}

Tauseef A. Bhat, R. Kotru, Akhil Verma, Monzoor A. Ganai, Latie, Latief A. Dar and Nazeer A. Teli. 2017. Leaf Colour Chart Based N Management for Yield, Nutrient Uptake and Yield of Rice Genotypes. Int.J.Curr.Microbiol.App.Sci. 6(9): 3531-3538.

doi: https://doi.org/10.20546/ijcmas.2017.609.434 